\title{
Subjective Reactions to Phonological Variation In Costa Rican Spanish ${ }^{1}$
}

\author{
Susan Berk-Seligson ${ }^{2}$
}

Accepted March 1, 1984

The results of a subjective reaction test on a sample of 440 Costa Ricans indicate that in societies where educational levels are not generally high, social status groups may be differentiated phonologically by the use of prestigeful features rather than by stigmatized ones, contrary to findings regarding social dialects in the United States. Participating listeners discriminated between three speakers whose reading of a Spanish text varied only according to their percentage use of stigmatized and prestige phonological variables-specifically, accent shift, vowel alternation, and consonantal alternation. As hypothesized, listeners assigned occupational status to, distanced themselves socially from, and attributed personality and socioeconomically related traits to speakers according to the degree of prestigefulness or stigmatization of the latter's speech. However, whereas listeners could distinguish well between the prestige speaker, on the one hand, and the intermediate and stigmatized speakers on the other, they barely differentiated between the latter two. Whereas male and female listeners did not differ significantly from each other in their reactions, contrary to expectation, older listeners, compared to younger ones, significantly more often discriminated between speakers in the expected direction, confirming further that sociolinguistic competence is acquired gradually.

Research in a variety of multilingual and multidialectal speech communities has found that listeners react subjectively to variations in speech. In

\footnotetext{
${ }^{1}$ This is a revised version of a paper presented at a meeting of the Linguistic Society of America, Boston, 1978. I would like to thank Robert L. Cooper, Adrienne Lehrer, Susan U. Phillips, Mitchell A. Seligson, and Patricia Van Metre for their helpful comments on earlier versions of this paper. I also wish to express my gratitude to the directors of the high schools that cooperated with this project, and to Jovita Castillo, Gabriel Castillo, and Francisco Mejía Mejía for their help in the construction of the questionnaire used in the study.

${ }^{2}$ Address all correspondence to Susan Berk-Seligson, Department of Foreign Languages and Literatures, Purdue University, West Lafayette, Indiana 47907.
} 
particular, studies have focused on the broadly gauged hypothesis that listeners judge speakers to be superior along various dimensions of personality if the speech of those speakers is characterized by high-status (prestige) variants, and, conversely, that they attribute negative personality characteristics to speakers who commonly use low-status (stigmatized) variants in their speech. Extensive research in this area of subjective reactions has been conducted by Lambert and his associates (Lambert, Hodgson, Gardner, \& Fillenbaum, 1960; Lambert, 1967; Lambert, Anisfeld, \& Yeni-Komshian, 1965; Lambert, Frankel, \& Tucker, 1966; Markel, Eisler, \& Reese, 1967; Brown, 1969; Tucker \& Lambert, 1969, 1972; D'Anglejan \& Tucker, 1973), and by Giles and his associates (Giles, 1970, 1971, 1973; Powesland \& Giles, 1975; Bourhis, Giles, \& Lambert, 1975; Giles \& Bourhis, 1976). Since these researchers have been carrying out their investigation in Canada and Great Britain, the overwhelming majority of the studies have focused on reactions to some variety of English. ${ }^{3}$ In the United States, as well, research of this type has focused on evaluative reactions to dialects of English (Shuy, 1968; Tucker \& Lambert, 1972). Only recently has there been some interest in subjective reactions to other languages, specifically Spanish, but this only in the context of contact with English (Williams, Hewett, Miller, Naremore, \& Whitehead, 1972; Carranza \& Ryan, 1975; Flores \& Hopper, 1975).

A common element in all of the above-mentioned studies is the evaluation of subjective reactions to speech varieties that correlate with sharply discernible social aggregates, either ethnic groups (e.g., the case of French and English in Canada, Black Vernacular versus standard English in the United States, Spanish versus English in the United States) or sharply defined social classes (e.g., the case of Received Pronunciation ${ }^{4}$ versus regional, lower-class dialects in Britain). None of the studies, to date, deals with social psychological attitudes toward linguistic variants that correlate with finely graded social stratification. ${ }^{5}$

${ }^{3}$ Exceptions are the studies of subjective reactions to French-speakers (Lambert, et al., 1960; D'Anglejan \& Tucker, 1973; Brown, 1969), to Hebrew- and Arabic-speakers (Lambert, et al., 1965; El-Dash \& Tucker, 1975; Cooper, Fishman, Lown, Schaier, \& Seckbach, 1977), to speakers of Swahili and Luyia (Scotton 1972), and to Spanish-Quechuan bilinguals (Wolck, 1973).

${ }^{4}$ Received Pronunciation is a term used to refer to that dialect of English used by the upper class in Britain. It is popularly referred to as "the Queen's English."

'Labov's (1966) classic study of New York City English, while it included a subjective reaction test, limited the scope of that test to socioeconomic findings, leaving aside socialpsychological variables. 
Subjective reaction test, or "verbal guise technique" studies, as Cooper (1975) has called them, ${ }^{6}$ not only have been limited to situations of sharp social differentiation but have largely been set in the social context of highly industrialized, urbanized, so-called developed countries. ${ }^{7}$ This leads one to question whether a research methodology of the verbal guise technique type can be successful in discovering speechrelated social-psychological attitudes only in the socioeconomic context of modern industrial society, or whether such a methodology has more far-reaching utility. It was with the intention of testing the utility of the

"Cooper's (1975, p.1) designation "verbal guise technique" comes as a useful cover term for the original "matched guise technique," as developed by Lambert et al., (1960), as well as subsequent variants of it. As devised originally, the technique consists of several recordings of a standard passage, by the same speaker, each version being read either in a different language or in a different dialect of the same language. Listeners are asked to rate the speakers on a series of personality traits. As the test is standardized, and the speaker remains constant for all the recordings, any significant differences that may emerge in listeners' ratings of the speaker's personality is attributed to differential attitudes toward the language variety that the speaker was employing. In other versions of the "matched guise technique," recordings are made not by one and the same speaker but by different speakers. This variant has been employed by Labov (1966), Bourhis and Giles (1976), Carranza and Ryan (1975), and Giles and Bourhis $(1975,1976)$. It was used in the present study as well. The drawback of this version of the "matched guise technique" is that it does not control for paralinguistic differences in the speech of the different speakers, thereby allowing for the possibility that such differences might result in a skewing of listener reactions to the voices. Nevertheless, the modified form of the verbal guise technique has one advantage over the original onenamely, it precludes the possibility of listeners recognizing that the voices on the various taped recordings belong to one and the same speaker. This is a particularly high risk in recordings where the linguistic differences between speakers are on the level of dialect rather than on that of language. Thus, there is a potential cost to be paid in terms of listener credulity when different dialectal versions of a passage are spoken by one and the same person. Therefore potential problems are inherent in both the original matched guise technique and the modified form of it that has been used here. Perhaps experimental designs programmed to measure the impact of each technique need to be conducted to help guide future research as to the suitability of one technique as opposed to the other.

Further variations in verbal guise techniques have to do with the nature of the material used to elicit subjective reactions. Whereas the classic use of a standard passage repeated several times has been criticized on the grounds that this makes listeners place greater emphasis on vocal variations in speech than would normally be the case in spontaneous discourse (Lee, 1971), only exceptionally have subjective reactions been elicited via anything other than standard passages, and when they have, it has been specifically for the purpose of discovering the impact of message content on listeners (e.g., Carranza \& Ryan, 1975; Powesland \& Giles, 1975). In the present study, where speech domain was not of interest, the classic use of a standard passage was adhered to.

${ }^{7}$ Notable exceptions to this are the work of El-Dash and Tucker (1975), Scotton (1972), Wolck (1973). 
verbal guise technique in a nonindustrialized country, in a socioeconomic context of finely graded stratification, and in a non-English linguistic setting that the present study was devised.

\section{METHOD}

\section{Research Setting}

This paper forms part of a larger investigation dealing with sociolinguistic aspects of Costa Rican Spanish (Berk-Seligson, 1978). For reasons briefly discussed below, Costa Rica presents a setting in which subjective reactions to speech can be tested in a situation of finely graded social stratification, and, given the fact that Costa Rica is a nonEnglish-speaking, developing nation, it provides an ideal setting for a study designed to overcome the limitations of previous research in the area of subjective reactions to speech.

In contrast to many other possessions of the Spanish colonial empire, at the time of discovery Costa Rica had an unusually small indigenous population, and this population was decimated in the earliest days of the colony. Consequently, for the past few centuries, Indians have constituted less than $1 \%$ of Costa Rica's total population. The only significant racial minority in the country is a group of Jamaican blacks, descendants of laborers who had come to Costa Rica in the last century to construct a railroad from the highlands to the Caribbean Sea. To this day, these blacks remain largely isolated in the Atlantic lowlands. Hence, ethnically speaking, Costa Rica is considered to be relatively homogeneous. Furthermore, because of the absence of gold and silver, and a sizable Indian work force, as a colony Costa Rica was extremely poor, so that all of the colonists and their descendants were compelled to take up farming in order to survive. As a result, the rigid social stratification found elsewhere in Latin America never developed in Costa Rica (Seligson, 1980). And, whereas in the 19th century coffee farming became a highly profitable enterprise and produced, for the first time, a wealthy class of planters, sharp social stratification never emerged. Indeed, many have argued that a primary explanation for Costa Rica's ability to develop civilian democratic rule, while nearly every other Latin American country has succumbed to authoritarian military control, is the absence of sharply defined social groupings in that country. 


\section{Hypotheses}

A number of phonological variables in Costa Rican Spanish, all of which are subsumed under the general categories of accent shift, vowel change, and consonantal change, have been shown to vary with fine distinctions in socioeconomic status (Berk-Seligson \& Seligson, 1978). In fact, they are sufficiently sensitive measures of socioeconomic status to predict nonlinguistic social attitudes and behavior (Seligson \& BerkSeligson, 1978), as will be seen in the concluding section of this paper. In a situation such as this, where fine social stratification and phonological variation are correlated with each other, a situation that contrasts markedly with a context where ethnic and social differences are sharply distinguishable, it remains to be asked whether listeners evaluate speakers differentially on the basis of speech differences. Thus, with this larger question in mind, the following hypotheses were formulated regarding users of Costa Rican Spanish:

1. On a scale of social distance, Costa Rican listeners will place themselves closer to those speakers whose phonological variants are predominatly prestige rather than stigmatized.

2. Costa Rican listeners are more positive toward speakers whose speech conforms phonologically to a prestigeful dialect, and are more negative toward those whose phonological variants are to a greater extent stigmatized, "positive" and "negative" being judged in terms of stated perceptions of listeners' personality, socioeconomic status (SES), and intelligence.

3. Costa Rican listeners are able to assign occupational categories to speakers purely on the basis of listening to phonological variation in their speech; they will assign progressively lower status occupations to speakers as the speech of the latter becomes progressively more stigmatized.

4. Costa Rican listeners are accurately able to judge the degree of "correctness" (adherence to a prestige norm) of the speech of several speakers whose use of prestige and stigmatized phonological forms varies.

5. Women will tend to perceive speakers who make more extensive use of prestige forms more positively than will men (i.e., will place themselves closer to them in terms of social distance, will attribute more positive traits to them, will assign them occupations of higher status, and will judge their speech as more "cor- 
rect" or "better" ). ${ }^{8}$ Conversely, they will be more negative than men in judging speakers who make more extensive use of stigmatized variants.

The last hypothesis, which entails the hypotheses that Costa Rican women make phonologically based social distinctions about people to a greater extent than men do, is constructed on the basis of findings to the effect that women's speech, at least at the phonological level, more closely approximates the prestigious pattern than does men's (Anshen, 1969; Fasold, 1968; Labov, 1972; Levine \& Crockett, 1966; Shuy, Wolfram, \& Riley, 1968; Trudgill, 1972; Wolfram, 1969). ${ }^{9}$

\section{The Test}

A standard passage was recorded by three Costa Ricans, each version of the passage differing from the others by the percentage use of stigmatized and prestige phonological variants (see Appendices A and B). Thus, one speaker pronounced all the variables in the prestige form, another speaker pronounced them all in a stigmatized fashion, and a third speaker pronounced $50 \%$ of the variables using stigmatized variants, and $50 \%$ using prestige variants, making sure that highly marked stigmatized variables (e.g., consonantal alternation of $[\mathrm{b} \sim \mathrm{g}]$, as in [bómitos $\sim$ gómitos]; accent shift, as in [oídos $\sim$ óydos]) were represented in the same proportion as variables that are nonprestige but mildly stigmatized (e.g., the deletion of [k] in consonant clusters, as in [awksílyo $\sim$ awsílyo]; [e $\sim \mathrm{i}]$ alternation, as in [peor pior]).

The listeners were asked first to rate each of the speakers (after hearing the tapes twice) on 13 pairs of polar opposite traits, the ratings to

\footnotetext{
${ }^{8}$ Throughout this paper references to "correct" and "better" speech will appear in quotation marks. They refer to widely held evaluations regarding the prestige norms of the speech community, and not to anything inherently correct or good about those norms. The terms thus embody a subjective reaction to a set of norms.

"The widespread, cross-culturally attested phenomenon of women speaking more "correctly" than men, at least in formal speech contexts (Labov, 1966), has been accounted for by various explanations, foremost among them being the generally greater status-consciousness of women (Trudgill, 1974), the need on the part of women to use status symbols (e.g., clothing, speech) to compensate for their lack of occupational status (Trudgill, 1972), the negative reaction of male schoolchildren to the female-teacher-dominated classroom, which leads them to reject various aspects of the school's value system, including standard forms of speech (Shuy, 1968), and finally, male attempts at acquiring what has been referred to as "covert prestige"' (Labov, 1966; Trudgill, 1972).
} 
be made on a 7 point scale going from "very $X$ " (where $X$ is an adjective) to "quite $X$," to "somewhat $X$," to " as $X$ as $Y$ " (where $Y$ is the polar opposite of $X$ ), to "somewhat $Y$," to " quite $Y$," to "very $Y$." The scale was presented in the form of a line divided into seven parts, such as the following one:

bueno malo

The seven-part division was chosen because of the finding by Osgood, Suci, and Tannenbaum (1957) that for scales of this type, fewer than seven divisions do not reveal a sufficient number of distinctions that the respondent is capable of making, and any number greater than seven renders meaningless the distinctions he or she makes.

The listeners were to check that segment of the line that best described how they felt about the speaker for any given pair of traits. Specifically, the traits were the following:

bueno: malo (good: bad)

simpático: antipático (friendly: unfriendly)

fuerte: débil (strong: weak)

trabajador: vago (hardworking: lazy)

inteligente: tonto (intelligent: dumb)

de confianza: desconfiable (trustworthy: untrustworthy)

activo: pasivo (active: passive)

honrado: deshonesto (honest: dishonest)

estimado: despreciable (esteemed: worthy of scorn)

generoso: tacaño (generous: stingy)

gentil: brusco (genteel: abrupt)

rico: pobre (rich: poor)

suave: mandón (easygoing: bossy)

The traits were selected on the basis of both the Osgood et al. (1957) cross-culturally attested findings as to the significance of three basic semantic dimensions (good/bad, strong/weak, active/passive) and the helpful commentaries of some Costa Rican friends (Castillo \& Castillo, 1973; Mejía Mejía, 1973).

Next, for each speaker, the listeners were to check "yes" or "no" to the following social distance questions:

1. Yo sería amigo de esta persona. (I would be a friend of this person.)

2. Yo aceptaría a esta persona como pariente político. (I would accept this person as a relative through marriage.)

3. Yo aceptaría a esta persona como vecino. (I would accept this person as a neighbor.) 
4. Yo le ayudaría a esta persona en el caso de que le haga falta algo. (I would help this person if he needed something.)

These items were taken from Lambert et al. (1965). Unlike the traits listed above, there is no evidence at all of their cross-cultural relevance for Costa Ricans.

Then, to see if the listeners could match each speaker with an occupation that would best correspond to him, they were asked the following questions:

1. ¿Cuál de los tres es peón? ${ }^{10}$ (Which one of the three is a worker?)

2. ¿Cuál de los tres es profesor? ${ }^{11}$ (Which one of the three is a professor?)

3. ¿Cuál de los tres es albañil? ${ }^{12}$ (Which one of the three is a mason?)

And finally, as a way of finding out for sure if the judgment of the listeners regarding all of the previously stated questions was consistent with their linguistic appraisal of the three speakers, the listeners were asked to answer these two questions:

1. ¿Cuál de los tres habló mejor? (Which one of the three spoke best?)

2. ¿Cuál de los tres habló peor? (Which one of the three spoke worst?)

Aside from all the substance-oriented questions, there were some questions requesting information on some standard demographic and socioeconomic measures-namely, respondent's age, sex, marital status, education, father's occupation, and father's income. These are generally considered to be valuable predictors of behavior.

${ }^{11}$ In Costa Rica peón refers to farm workers as well as to blue-collar workers.

${ }^{11}$ The word profesor is used in Costa Rica to refer both to high school teachers and college professors.

${ }^{12}$ Note that whereas an occupational categorization could have been elicited from informants by a more open-ended procedure-namely, by asking them to suppose what kind of occupation each speaker might have had-it was decided instead to supply informants with the three specified alternatives so as to ensure a hierarchical ranking, and to avoid eliciting from any one informant occupations that were similar or equal in rank. This approach has the unfortunate consequence of precluding the possibility of equal rankings in cases where informants perceived two given speakers to be occupationally indistinguishable, but it has the advantage of guaranteeing rank orderings, which was the goal of the task. 


\section{Subjects}

The sample (total $N=440$ ) consists primarily of ninth-grade high school students (56.9\%) and fifth- and sixth-grade elementary school students $(30.6 \%)$, the rest of the respondents consisting of seventh- and eighth-grade night school students (10.4\%) and adults living in Sabanilla de Montes de Oca (2.2\%), an area in which other phonologically oriented sociolinguistic studies were being carried out. The schools from which the sample was drawn were the Colegio Anastasio Alfaro, an all-girls public high school; the Liceo de Costa Rica, an all-boys public high school; Escuela José Figueres, an elementary school; and a night school that is run in the Colegio Calasanz. As for the sex of the respondents, of those who responded to this question $(2.7 \%$ did not, which meant that this percentage of the sample was dropped from any analysis of male/female differences), $40.4 \%$ are male and $59.6 \%$ are female.

The ages of the respondents range from a low of 10 years to a high of $47,27.9 \%$ of the sample being 13 years old and younger, $69.6 \% 15$ years old and younger, and $88.1 \% 17$ years old and younger. The 17-year-old and younger group constitutes the daytime elementary and secondary school students, whereas the remaining $11.7 \%$ of the sample, the 18-andolder group, consists of night school students (essentially, people in their late teens and 20s) and Sabanilla adults (those in the sample whose ages are predominantly in the 40s). The inclusion of children as well as adults was intentional, for one important area of inquiry in the field of sociolinguistics is the acquisition of sociolinguistic competence, ${ }^{13}$ and it was expected that the various sorts of subjective reactions investigated here would vary according to the age of the speaker.

Unfortunately, responses to the occupation and income questions were, in the vast majority of cases, either too vague (in the case of occupation) or missing (in the case of income). Responses such as " $\mathrm{He}$ works in the Coca-Cola bottling plant" revealed nothing about the status of the occupation, since the subject's father could have been a worker on an assembly line or a janitor, or else a foreman or even an executive. As for knowledge of their parents' income ${ }^{14}$ this was so often not known by

\footnotetext{
${ }^{13}$ The notion of sociolinguistic competence as something that is acquired and the contrast between child and adult discourse strategies have been the subject of much recent study. They have been explored, for example, by Keenan (1973, 1974), Cook-Gumperz (1975), MitchellKernan and Kernan (1975), and Gumperz and Herasimchuk (1975). As for the acquisition of phonological norms, the subject has been treated by Labov (1965).

${ }^{14}$ For nonworking respondents, "income" refers to parents" income.
} 
the students (48.4\% of the respondents did not respond) that correlations could not be made between income and other variables. Nevertheless, some observations can still be made on the basis of the $51.6 \%$ who did respond. For one thing, $12.1 \%$ were at the bottom of the scale (less than 300 colones ${ }^{15}$ per month, then the salary of a farm worker), and a similar percentage $(11.2 \%)$ were at the top of the scale (more than 4,000 colones per month, or the income of a large businessman or a professional). As can be seen in Table I, income was distributed quite evenly across the gradations. Thus, apparently all the various income levels were fairly well represented in the sample.

With an idea of the nature of the sample in mind, it is now possible to present the findings.

\section{RESULTS}

\section{Hypothesis 1}

That Hypothesis 1 (i.e., listeners will place themselves closer to those speakers whose phonological variants are predominantly prestige rather than stigmatized) is in fact confirmed is perhaps the most telling evidence in the process of proving that the phonological variables under investigation are indeed socially salient. Table II reveals how the listeners

Table I. Monthly Income

\begin{tabular}{lc}
\hline Income (in colones) & \% of respondents ${ }^{a}$ \\
\hline Less than 300 & 12.1 \\
From 301 to 500 & 7.8 \\
From 501 to 750 & 8.6 \\
From 751 to 1,000 & 14.7 \\
From 1,001 to 1,500 & 13.8 \\
From 1,500 to 2,000 & 9.1 \\
From 2,001 to 3,000 & 13.8 \\
From 3,001 to 4,000 & 9.1 \\
more than 4,000 & 11.2 \\
\hline
\end{tabular}

${ }^{a}$ Note that only $51.6 \%$ of the respondents answered the question concerning income.

\footnotetext{
${ }^{15}$ At the time of the study, 8.6 colones were equal to $\$ 1$ U.S.
} 
Table II. Mean Score ${ }^{a}$ Regarding Speakers on Social Distance Scale

\begin{tabular}{lccccc}
\hline & $\begin{array}{c}\text { Prestige } \\
\text { speaker }\end{array}$ & $\mathrm{Sig}^{b}$ & $\begin{array}{c}\text { Intermediate } \\
\text { speaker }\end{array}$ & $\mathrm{Sig}^{b}$ & $\begin{array}{c}\text { Stigmatized } \\
\text { speaker }\end{array}$ \\
\hline Accept as relative & & & & & \\
$\quad$ through marriage & 1.38 & $<.001$ & 1.55 & .03 & 1.60 \\
Accept as friend & 1.10 & $<.001$ & 1.22 & n.s. & 1.25 \\
Accept as neighbor & 1.01 & $<.001$ & 1.19 & n.s. & 1.23 \\
Help if in need & 1.06 & .03 & 1.10 & n.s. & 1.09 \\
\hline
\end{tabular}

${ }^{a}$ Note that responses were coded as follows: $1=$ yes, $2=$ no. Thus, the lower the score, the more positive were the listeners toward a given speaker; conversely, the higher the score, the more negative were the listeners.

${ }^{b}$ Significance levels are $t$ tests. Hotelling's $T^{2}$ test performed on all three speakers reveals that for the first three social distance measures significance is $<.001$, but that for the "help if in need" measure no overall statistically significant results are obtained. It should be noted that the significance tests employed in this table and in the others presented in this paper are used to help distinguish between results that are insufficiently different to merit attributing to them substantive significance for the given sample size. While in traditional statistical applications significance tests are applied only to data derived from probability samples, much current social science practice favors their use as employed herein.

The significance level indicated in the second column is the test between the prestige speaker and the intermediate speaker. The significance level indicated in the fourth column is the test between the intermediate speaker and the stigmatized speaker.

placed themselves socially vis-à-vis each of the speakers, demonstrating that the more prestigious was a speaker's choice of variants, the more acceptable was that speaker to the listeners. Thus, in general, for each category of social distance, listeners placed themselves closest (i.e., scores approaching 1 rather than 2) to the speaker who used only prestige variants, farthest away from the speaker who used only stigmatized variants, and somewhere in between in relation to the speaker who used prestige forms for $50 \%$ of the variables and stigmatized forms for the other $50 \%$. It should be noted that there is one exception to the generalization, and that is in the case of "helping the speaker if he were in need"': Here the intermediate speaker fared slightly worse (by .01) than the stigmatized speaker; the difference, however, is not statistically significant. But perhaps what is even more interesting about the scores for this category is their similarity $(1.07,1.10$, and 1.09). Whereas for all the other social distance categories there are large differences between the mean scores for the prestige and intermediate speakers (differences of $.17, .12$, and .18), for the "help if in need" category the difference in means between the two speakers is slight (merely .03). What suggests 
itself here is the possibility that there is something special about this category, something that neutralizes whatever social differences may be perceived in regard to the speakers, for, whether the speaker is an upper SES type, a lower SES type, or someone somewhere in between, listeners seem to be nearly equally willing to help him if he were in need. Whereas at first glance this finding might seem puzzling, once sociohistorical and cultural factors are taken into account, the verbalized willingness of Costa Ricans to help others in need, despite perceived differences in the latter's socioeconomic background, can be understood. What appears to have happened is that the relatively egalitarian historical social structure has resulted in a blurring of sharp social status demarcations. Hence, whereas Costa Ricans may be able to recognize socioeconomically related linguistic markers, this does not hamper their stated desire to help needy persons coming from divergent social backgrounds.

The responses to the social distance questions also reveal that listeners place a much larger distance between the prestige speaker and the intermediate speaker, on the one hand, than between the intermediate speaker and the stigmatized speaker, on the other. A look at Table II reveals that, with the exception of the "help if in need" category, the differences between the mean scores for columns 1 and $2(.17, .12$, and $.18)$ are far greater than they are for columns 2 and $3(.05, .03$, and .04$)$, looking from top to bottom. In fact, whereas the differences between the mean scores for the first two columns are statistically significant, those for the last two are not (with the exception of "accept as a relative through marriage"). This unexpected finding possibly may be accounted for by the explanation that the listeners did not distinguish very sharply between the intermediate and the stigmatized speaker, whereas they distinguished to a high degree between the prestige speaker (whose speech was characterized by the total absence of stigmatized variants), on the one hand, and the other two speakers (whose speech was marked by the use of stigmatized variants in varying degrees), on the other hand.

An alternative explanation of the failure of respondents to distinguish between the intermediate and stigmatized speakers is the factor of age. Possibly, the youngest respondents, not being as aware of the social significance of phonological variation as are older adolescents, ${ }^{16}$ pulled down the overall percentages of all the respondents. If one looks at the responses of the older adolescents, however, one finds that they, the 16-

\footnotetext{
${ }^{16}$ Labov $(1964$, p. 100$)$ pinpoints 17 or 18 as the age at which an adolescent becomes completely familiar with the social norms of his speech community.
} 
to 17-year-olds, are no more capable of distinguishing between the intermediate and stigmatized speakers than are the youngest respondents, those 10-13 years of age. Some weak support for the "age" hypothesis does emerge, nevertheless, insofar as the adult respondents, who range in age from 18 to 47 , did distinguish between the intermediate and stigmatized speakers on the "accept as a relative through marriage" item. Indeed, it is only this age category that reveals a significant difference in attitudes toward the intermediate and stigmatized speakers, and this explains why the overall results for the "accept as a relative through marriage" item, presented in Table II, for all respondents in the study demonstrate a significant difference in the evaluation of these two speakers. In short, irrespective of age, the respondents in the study found it very difficult to distinguish between the intermediate and stigmatized speakers.

\section{Hypothesis 2}

Do Costa Rican listeners attribute more positive characteristics to speakers according to the frequency with which the latter use stigmatized or prestige phonological variants? A look at Table III should provide the answer to this question.

The strongest piece of evidence available for the confirmation of Hypothesis 2 is the fact that the prestige speaker is rated much more positively, far above the other two, on every pair of traits, without exception. Thus, he is considered to be better, friendlier, stronger, more hardworking, more intelligent, more trustworthy, more active, more honest, more worthy of esteem, more generous, more genteel, wealthier, and more compliant than either of the other two speakers. This finding conforms precisely to what was expected.

What is not fulfilled is the expectation that the intermediate speaker would in turn be rated more highly than the stigmatized speaker on every trait. In fact, on only 5 out of the 13 pairs of characteristics are the ratings in the predicted direction (inteligenteltonto, activelpasivo, estimado/ despreciable, gentil/brusco, and rico/pobre). Nevertheless, it should be noted in regard to the ratings that were contrary to expectation that, on the whole, the differences between the scores for the two speakers were so small as to be statistically insignificant. Thus, for example, if the mean score on de confianzaldesconfiable was 3.55 for the intermediate speaker and 3.51 for the stigmatized speaker, it cannot be claimed that the listeners perceived the intermediate speaker to be more trustworthy than the 
Table III. Mean Score for Each Speaker by Adjective Pair ${ }^{a}$

\begin{tabular}{lccccc}
\hline \multicolumn{1}{c}{ Adjective pair } & $\begin{array}{c}\text { Prestige } \\
\text { speaker }\end{array}$ & Sig. ${ }^{b}$ & $\begin{array}{c}\text { Intermediate } \\
\text { speaker }\end{array}$ & Sig. ${ }^{b}$ & $\begin{array}{c}\text { Stigmatized } \\
\text { speaker }\end{array}$ \\
\hline Bueno/malo & 2.07 & $<.001$ & 3.04 & n.s. & 2.89 \\
Simpático/ & & & & & \\
$\quad$ antipático & 2.98 & $<.001$ & 3.78 & n.s. & 3.56 \\
Fuerte/débil & 3.56 & $<.001$ & 4.11 & n.s. & 3.96 \\
Trabajador/vago & 2.22 & $<.001$ & 3.07 & n.s. & 2.87 \\
Inteligente/tonto & 2.07 & $<.001$ & 3.42 & $<.001$ & 3.97 \\
De confianza/ & & & & & \\
$\quad$ desconfiable & 2.94 & $<.001$ & 3.55 & n.s. & 3.51 \\
Activo/pasivo & 3.35 & .011 & 3.72 & .02 & 3.94 \\
Honrado/deshonesto & 2.09 & $<.001$ & 2.82 & .04 & 2.62 \\
Estimado/ & & & & & \\
$\quad$ depreciable & 2.52 & $<.001$ & 3.24 & n.s. & 3.30 \\
Generoso/tacaño & 2.73 & $<.001$ & 3.53 & $<.001$ & 3.10 \\
Gentil/brusco & 2.34 & $<.001$ & 3.24 & n.s. & 3.26 \\
Rico/pobre & 3.91 & $<.001$ & 4.46 & $<.001$ & 5.25 \\
Suave/mandón & 3.01 & .001 & 3.42 & .05 & 3.20 \\
\hline
\end{tabular}

${ }^{a}$ Note that the lower the mean, the more favorable the rating.

${ }^{b}$ These significance levels are $t$ tests between the indicated pairs of speakers. Hotelling's $T^{2}$ test performed on all three groups (test-retest) reveals that $p<.01$ in every case and is $<.001$ in 10 of the 12 adjective pairs.

stigmatized speaker, since the difference between the mean scores (.04) is not statistically significant and, therefore, may be attributable to mere chance. All it means is that the listeners did not detect any appreciable difference in trustworthiness between the two speakers.

Once again, the possibility that the age factor may have prevented the respondents from distinguishing between the intermediate and stigmatized speakers was explored. As in the previous analysis, age proved to have no bearing on the findings. Specifically, an analysis of the younger versus the older students did not produce any additional significant differences between the ratings of the intermediate speaker and those of the stigmatized speaker. Indeed, not even the adults proved to be any more capable of distinguishing between the two speakers than did the sample as a whole.

Why is the intermediate speaker not rated consistently more positively than the stigmatized speaker? One possibility that comes to mind is that the amount of phonological variation between the two was not sufficiently great as to allow the listeners to differentiate accurately between 
them. But such an explanation must be discarded because of two pieces of evidence to the contrary. If one looks carefully once again at Table III, one will notice that on two pairs of traits (rico/pobre, inteligente/tonto), the three speakers were rated in the predicted manner, and, more important, the differences between the scores for the prestige and the intermediate speaker, and between those for the intermediate and the stigmatized speaker are both quite large, suggesting that on these particular attributes the three speakers were clearly distinguishable for the listeners. There happens to be something rather special about these traits, something that distinguishes them from the other characteristics, and that is that rather than being essentially personality traits, they are socioeconomic status-linked traits. The pair ricolpobre can obviously be understood to be an SES measure. The traits inteligente/tonto are not obviously so. Although, on the surface, they appear not to be statuslinked characteristics, in reality they are automatically associated by Costa Ricans with corresponding education levels (i.e., if a person has had many years of schooling he is assumed to be intelligent; if he has had very little schooling, he is assumed to be dumb). Even though intelligence and education are by no means necessarily associated, popular opinion in Costa Rica (and elsewhere, for that matter) links the two, particularly in the case of judging people at the lower and upper extremes of educational attainment.

In effect, then, by distinguishing so clearly among the three speakers on the attributes of wealth and intelligence, the listeners were spacing the speakers in terms of SES, and they did so in the expected direction. When it came to personality traits, however, the listeners could distinguish clearly only between the prestige speaker, on the one hand, and the intermediate and stigmatized speakers, on the other, but not between the intermediate and stigmatized speakers in relation to each other. Apparently, then, the degree of phonological variation that differentiated the speech of the intermediate and stigmatized speakers was not sufficient to enable the listeners to deem one speaker superior to the other on all of the personality traits, as the listeners had been able to do with the prestige speaker in relation to the other two.

Still puzzling, nevertheless, is the question as to why the listeners, on so many traits, rated the stigmatized speaker higher than the intermediate one even if many of the differences in scores were statistically insignificant. It would seem that the answer lies in paralinguistic features of the speakers' speech. Any one element alone or a combination of several elements (e.g., pitch, stress, juncture, loudness, speed, individual voice quality) may have served to give the listeners the impression that 
the stigmatized speaker was in several aspects a "nicer" person than the intermediate speaker.

\section{Hypothesis 3}

What of Hypothesis 3 ? Did the listeners assign occupational categories to the speakers in the anticipated manner, matching the progressively higher status occupations with the speakers according to the degree to which the latter used prestige and stigmatized phonological variants? Looking at the sample as a whole, one can say with assurance that the hypothesis is confirmed (although perhaps not as impressively as had been anticipated). The highest status occupation, professor, was assigned to the prestige speaker by $68.1 \%$ of those who responded $(18.9 \%$ believed that the stigmatized speaker was the professor, and $12.9 \%$ assigned that occupation to the intermediate speaker). The intermediate occupational rank, mason, was correctly matched up with the intermediate speaker by $66.7 \%$ of those who responded $(14.9 \%$ chose the stigmatized speaker, and $18.3 \%$ the prestige speaker). And $62.3 \%$ matched the occupation of laborer with the stigmatized speaker (while $16.5 \%$ attached that occupation to the prestige speaker, and $21.2 \%$ linked it to the intermediate speaker).

Why are the percentages not any more dramatic than they are? One possible reason may be that the two lower-status occupations are not sufficiently wide apart for people to distinguish between them. Perhaps if an occupation higher than mason had been chosen (e.g., merchant), or, alternatively, if "laborer" (peón) had been specified as "farm worker" (peón agrícola), then a higher percentage of listeners might have judged correctly.

Another possible explanation for the not-so-startling results is that the youngest respondents (the fifth- and sixth- grade students), perhaps ' not being as aware of the social significance of phonological variation as are older adolescents and simultaneously not being as aware, either, of the differences in status between occupations, pulled down the overall percentages. This hypothesis can be tested out by looking at the responses of only the 16- and 17-year-olds. The increase in accuracy is quite dramatic. Of those who responded, $82.4 \%$ matched the occupation of professor with the prestige speaker , 78.1\% linked "mason" with the intermediate speaker, and $76.4 \%$ guessed the stigmatized speaker to be a laborer. Thus, given the greater inaccuracy of the fifth- and sixth-grade schoolchildren relative to the rest of the sample, and given the element of 
error that always is present in the responses to any question, Hypothesis 3 . must be said to be confirmed.

\section{Hypothesis 4}

Coming now to the hypothesis that Costa Rican listeners will judge the "correctness" of a speaker's speech according to the degree to which prestige and stigmatized forms are used, one may look at the responses to the questions "Which of the speakers spoke best?" and "Which of the three speakers spoke worst?" The responses to these questions closely parallel the findings regarding the third hypothesis. On the answer to the first question, $77.1 \%$ of those who responded did so as hypothesized (i.e., chose the prestige speaker), and in reply to the second question, $66.3 \%$ were accurate (i.e., chose the stigmatized speaker). Once again, checking the 16 years and older group, to see if the younger respondents were not lowering the overall percentages, it is found that of the 16- and 17-year-olds who answered the two questions, $87.8 \%$ answered the first one as anticipated, and $77.5 \%$ answered the second one as expected. Thus, Hypothesis 4 is confirmed as well.

One finding that becomes clear upon seeing the percentages for both Hypothesis 3 and Hypothesis 4 is that the prestige speaker is more correctly identified (in terms of occupation and "best" speech) than are the other two speakers. Again, this is consistent with the findings uncovered in previous sections of the study: The prestige speaker stands out for the listeners and is set apart from the other two.

It is not coincidental that the fourth hypothesis is confirmed, given the validation of the first three. For underlying listeners' discrimination between phonologically differentiated speakers, along the lines of social distance, traits related to personality, SES, and intelligence, and to occupational categorization, is the sensitivity to prestige and stigmatized phonological norms. Listeners' ability to distinguish "correct" speech from stigmatized speech enables them to make the kinds of discriminations verified by Hypotheses 1, 2, and 3. If the fourth hypothesis had not been validated, it seems unlikely that the first three could have been.

\section{Hypothesis 5}

Now that the hypotheses have been examined from the point of view of the entire sample of respondents, they may be investigated from the 
perspective of male/female differences in responses. Hypothesis 5namely, that women will react more favorably than men to speakers who make greater use of prestige variants, and more negatively than men to speakers who use stigmatized variants more extensively - can be either confirmed or rejected upon examination of Table IV. Table IV presents the statistically significant differences between male and female reactions to the three speakers regarding (1) social distance, (2) personality and other traits, (3) occupational status, and (4) "correctness" of speech. As is evident from the table, on the whole, there are very few significant differences in response according to the sex of the respondent. Where the differences do occur, however, they are in the predicted direction-

Table IV. Significant ${ }^{a}$ Differences Between Male and Female Responses

\begin{tabular}{|c|c|c|c|c|c|c|c|c|c|}
\hline & \multicolumn{3}{|c|}{ Prestige speaker } & \multicolumn{3}{|c|}{ Intermediate speaker } & \multicolumn{3}{|c|}{ Stigmatized speaker } \\
\hline & Male & Female & Sig. & Male & Female & Sig. & Male & Female & Sig. \\
\hline $\begin{array}{l}\text { Accept as relative } \\
\text { through marriage } \\
\text { Accept as friend } \\
\text { Accept as neighbor } \\
\text { Help if in need }\end{array}$ & 1.467 & 1.330 & .005 & 1.142 & $1.07 \mathrm{I}$ & .024 & & & \\
\hline $\begin{array}{l}\text { Bueno/malo } \\
\text { Simpático/antipático } \\
\text { Fuerte/débil }\end{array}$ & 3.827 & 3.398 & .045 & & & & & & \\
\hline $\begin{array}{l}\text { Trabajador/vago } \\
\text { Inteligente/tonto } \\
\text { De confianza/confiable } \\
\text { Activo/pasivo } \\
\text { Honrado/deshonesto } \\
\text { Estimado/despreciable }\end{array}$ & & - & 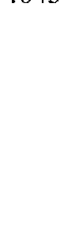 & 3.169 & 3.577 & .011 & $\begin{array}{l}3.651 \\
3.645\end{array}$ & $\begin{array}{l}4.217 \\
4.114\end{array}$ & $\begin{array}{l}.002 \\
.023\end{array}$ \\
\hline $\begin{array}{l}\text { Generoso/tacaño } \\
\text { Gentil/brusco } \\
\text { Rico/pobre } \\
\text { Suave/mandón }\end{array}$ & 4.174 & 3.750 & .026 & & & & 2.983 & 3.461 & .010 \\
\hline $\begin{array}{l}\text { Peón } \\
\text { Albañil } \\
\text { Profesor }\end{array}$ & & & & & & & & & \\
\hline $\begin{array}{l}\text { Habló mejor } \\
\text { Habló peor }\end{array}$ & & & & & & & & & \\
\hline
\end{tabular}

${ }^{a}$ The criterion for significance is .05 or less. Where no significant difference appears, a blank is left in the table. 
namely, the women's scores are lower (more positive) in the case of the prestige speaker and higher (more negative) in the case of the intermediate and stigmatized speakers, the only exception being "would help the speaker if he were in need," in which case women place themselves closer to the intermediate speaker than do men. Overall, however, only 8 of the possible 66 differences $(12 \%)$ proved to be statistically significant. The results, as presented in Table IV, provide only very weak support for Hypothesis 5 .

Once again the possibility suggests itself that the scores of the younger respondents are obscuring differences that may in fact exist between male and female responses. If the sample is broken down into age groups, and significant differences according to sex of respondent are sought out, as was done for the sample as a whole, one finds the following (see Table V): In the 13-year-old-and-younger group there are no significant differences at all between boys and girls. In the 14- to 15-yearold group several (8) significant differences appear; in the 16- to 17-yearold group there are only 2 ; and in the 18-years-and-older group there are 10. One sees, then, that by dividing the entire sample into age groups one finds within any given age group the same, or an even greater, paucity of statistically significant differences between male or female responses as there was in the sample as a whole. Thus, viewing males and females by age groups has not been of any use in revealing differences that were thought to exist. Its only utility has been to further reinforce the impression given by those male/female differences that are statistically significant for the sample as a whole - namely, that women do react more favorably to the prestige speaker than do men, and more negatively to the stigmatized speaker than do men. ${ }^{17}$ Their reaction to the intermediate speaker, however, is more ambivalent (i.e., favorable sometimes, negative at others) when viewed from the perspective of the various age groups than it is when examined in the context of the entire sample. Apparently, only the prestige and stigmatized speakers are able to evoke consistent reactions from the listeners according to the latter's sex.

\section{CONCLUSIONS AND IMPLICATIONS}

The findings of this study have shown that Costa Rican listeners can, in fact, determine accurately which of three speakers speaks a phonologi-

\footnotetext{
${ }^{17}$ The only exception to the pattern lies in the responses of the 16- to 17-year-olds. In this case females were more positive toward the stigmatized speaker then were males.
} 
Table V. Significant ${ }^{a}$ Differences Between Male and Female Responses, by Age Group

\begin{tabular}{lcc}
\hline & \multicolumn{2}{c}{ Mean Score } \\
\cline { 2 - 3 } & Males & Females \\
\hline 13 years old and younger & & - \\
14 to 15 years old & & \\
(Prestige) accept as relative through & & \\
$\quad$ marriage & 1.475 & 1.314 \\
(Intermediate) accept as neighbor & 1.267 & 1.127 \\
(Prestige) fuerte/débil & 3.900 & 3.084 \\
(Prestige) rico/pobre & 4.000 & 3.405 \\
(Stigmatized) fuerte/débil & 2.983 & 3.787 \\
(Stigmatized) inteligente/tonto & 3.650 & 4.383 \\
(Stigmatized) estimado/despreciable & 3.065 & 3.866 \\
(Stigmatized) gentil/brusco & 3.164 & 3.748 \\
16 to 17 years old & & \\
(Stigmatized) de confianza/desconfiable & 4.367 & 3.333 \\
(Stigmatized) generoso/tacaño & 3.581 & 2.653 \\
18 years and older & & \\
(Prestige) accept as friend & 1.227 & 1.030 \\
(Prestige) accept as relative through & & \\
$\quad$ marriage & 1.429 & 1.152 \\
(Intermediate) accept as relative & & \\
$\quad$ through marriage & 1.667 & 1.375 \\
(Prestige) trabajador/vago & 2.435 & 1.438 \\
(Prestige) inteligente/tonto & 2.450 & 1.517 \\
(Prestige) honrado/deshonesto & 2.125 & 1.321 \\
(Prestige) gentil/brusco & 2.348 & 1.387 \\
(Stigmatized) activo/pasive & 3.391 & 4.759 \\
(Stigmatized) gentil/brusco & 1.900 & 2.963 \\
(Intermediate) de confianza/desconfiable & 2.818 & 2.964 \\
\hline
\end{tabular}

${ }^{a}$ The criterion for significance is .05 or less

cally prestige social dialect, which one speaks a stigmatized variety, and which one falls in between the two types. In addition, listeners are able to assign an expected occupational status to each of three speakers on the basis of phonological variation in the latter's speech, although this is less true of younger listeners (13 years old and younger) than it is of older ones (16 and 17 years old). Furthermore, listeners place themselves in terms of "social distance" to speakers according to the degree to which speakers use prestige and stigmatized phonological variants; however, the spacing is not equidistant. Listeners place themselves much closer to a 
speaker who uses only prestige forms than they do to speakers who either use only stigmatized forms or use $50 \%$ prestige and $50 \%$ stigmatized variants. Another finding has been that despite the fact that listeners can place speakers fairly equidistantly on a scale of rich/poor and intelligent/ dumb, in accordance with the degree to which the speakers use prestige and stigmatized phonological variants, they distinguish a "prestige speaker" from both a "stigmatized speaker" and an "intermediate speaker" on a series of personality traits, rating the prestige speaker more positively than the other two in every way, but do not discriminate similarly between the intermediate and the stigmatized speaker. This unexpected nonparallel relationship may possibly be accounted for by paralinguistic factors present in the speech of the two persons whose voices were recorded. Finally, concerning male/female differences in regard to all the other hypotheses tested, it was found that relatively very few such differences exist, but that whenever they do, females are more positive toward the prestige speaker than men are, and more negative toward the intermediate, and particularly so toward the stigmatized speaker, then men are.

Several questions are raised by the above-mentioned findings. If, on the whole, the listeners discriminated sharply between the prestige speaker, on the one hand, and the intermediate and stigmatized speakers, on the other, but only slightly between the intermediate and the stigmatized speaker, how much more "correctly" (i.e., to what extent more prestigiously) would the intermediate speaker have to have spoken for the listeners to have separated him farther away from the stigmatized speaker. If $50 \%$ prestige was not sufficient, what percentage would have been: $75 \%$, or something much higher? Could the findings be interpreted to mean that it is not so much the case that the intermediate speaker is perceived negatively (because he uses so many of the forms that the stigmatized speaker does), but that the prestige speaker strikes the listeners somehow as an idealized speaker, as the "marked" number of the set, whereas the other two are "unmarked"'? The interpretation that prestige speech is marked in Costa Rica is a highly plausible one, given the numerous types of stigmatized variants that exist in the speech of the population and the unlikelihood of uniformly prestige speech, even at formal contextual levels. If this should turn out to be the case, it would be a significant, contrastive finding in relation to the way in which social differentiation in language operates in the United States. For, as Wolfram and Fasold (1974) have alluded, and Wolfram and Christian (1976, p. 17) have reiterated: 
Status groups are more often differentiated by the usage of socially stigmatized features than they are by the usage of socially prestigious ones. In fact, it is tempting to define standard varieties of English in terms of their relative absence of socially stigmatized features used by non-mainstream groups as opposed to the socially prestigious features which may be found among high status groups. This pattern would contrast with that of a society which emphasized differentation in terms of socially prestigious features rather than stigmatized ones.

This article began as an attempt to determine whether the verbal guise technique could be useful in a set of circumstances that are distinct from those in which it has been normally carried out. Specifically, the present study has sought to discover to what extent such a subjective reaction test can be effective in a situation where (1) the language in question is not English and is not in a language-contact relation to English; (2) the population of speakers constitutes a community that is socioeconomically finely graded, rather than being cleft by either ethnic groups or sharply definable social class groups; and (3) the national economic setting is one of underdevelopment, rather than industrial development. The case of Spanish in Costa Rica represents the intersection of these three characteristics and thus stands in marked contrast to the circumstances under which verbal guise technique studies have been carried out in the past. This study has demonstrated that, indeed, subjective reaction tests of this type work equally well in a variety of linguistic, social, and national economic settings.

Seeing that the verbal guise technique is a robust methodological instrument encourages one to use it for other social scientific inquiries, beyond the realm of linguistics. Specifically, it is suggested that its use be included in nonlinguistic social science surveys, as one stage in the process of utilizing sociolinguistic variables for the prediction of nonlinguistic social attitudes and behavior. Having been incorporated into a larger study (Seligson \& Berk-Seligson, 1978), which analyzed political participation among Costa Rican peasants, the verbal guise technique was seen to be a crucial step in selecting the linguistic variables that in turn formed part of an overall measure of socioeconomic status. Thus, while useful for discovering direct relationships between speech and social psychological attitudes, subjective reaction tests such as the verbal guise technique can also be a tool for the ultimate prediction of social attitudes and behavior that are nonlinguistic. And, although other scholars (Gaertner \& Bickman, 1971; Powesland \& Giles, 1975) have already begun putting the verbal guise technique to more general social scientific use, its wider applicability nonetheless still remains relatively unexplored. 


\section{APPENDIX A}

\section{Taped Text of Subjective Reaction Test}

Era el peor momento de su vida. Sentado frente al ataúd en el cual descansaba la difunta, Felipe ignoraba absolutamente lo que pasaba alrededor de él. Le era increíble creer que su abuela realmente se había muerto. La recaída del bronquitis había sido suficiente para matarla, y no había ninguna cápsula ni inyección que podía darle auxilio ahora.

El la recordaba frente al fogón, haciéndole huevos para el almuerzo, o moliendo maíz para aquellas tortillas perfectas y magníficas por las cuales era tan admirada. Ella había sido la viuda de un pobre jornalero por un periodo de veinte años.

Al ver llegar de afuera a su maestro don Rafael y al Padre Antonio, le subío a la garganta un nudo, casi como un ahogo que le iba a producir vómitos, tal fue la impresión. La sangre le zumbaba en sus oídos como un río bravo, y creía que se había caído del banquito, se sentía tan débil. Quería huir de sí mismo.

Ya estaba oscuro el cielo. Su maestro le decía al oído: "Cuando creemos en Dios, no huímos de la muerte. La admitimos; la aceptamos. Dios nos trae el consuelo."

El día siguiente, sentado en su pupitre después de cantar el himno nacional, se sentía mejor, como si fuera posible que algún día sería capaz de reírse de nuevo.

\section{APPENDIX B}

\section{English Translation of Subjective Reaction Test Text}

It was the worst moment of his life. Seated in front of the coffin in which the deceased woman rested, Philip was completely unaware of what was happening around him. It was impossible for him to believe that his grandmother really had died. The relapse of bronchitis had been enough to kill her, and there was no capsule or injection that could help her now.

He remembered her in front of the hearth, making him eggs for lunch, or grinding corn for those perfect, magnificant tortillas for which 
she was so admired. She had been the widow of a poor day worker for a period of twenty years.

Upon seeing his teacher, don Rafael, and Father Antonio arrive from outside, there arose in his throat a knot, almost like a suffocation which was going to provoke vomiting in him, so moved was he. His blood rang in his ears like an angry river, and he thought that he had fallen off his little stool, so weak did he feel. He wanted to flee from himself.

The sky was dark already. His teacher was saying to him in his ear, "When we believe in God we don't flee from death. We let it come in; we accept it. God brings us solace."

The following day, seated at his school desk, after singing the national anthem, he felt better, as if it were possible that some day he would be capable of laughing once again.

\section{APPENDIX C}

Subjective Reaction Test Variables

\begin{tabular}{|c|c|c|c|}
\hline $\begin{array}{c}\text { Type of phonological } \\
\text { variable }\end{array}$ & $\begin{array}{l}\text { Lexical } \\
\text { item }\end{array}$ & $\begin{array}{c}\text { Prestige } \\
\text { pronunciation }\end{array}$ & $\begin{array}{c}\text { Stigmatized } \\
\text { pronunciation }\end{array}$ \\
\hline \multicolumn{4}{|l|}{ Accent shift } \\
\hline & increible & [inkreíble] & [1nkréible] \\
\hline & recaída & [rekaída] & [rekáyda] \\
\hline & oídos & [oídos] & [óydos] \\
\hline & oído & [oído] & [óydo] \\
\hline & maíz & [maís] & [máis] \\
\hline & período & [período] & [periódo] \\
\hline & maestro & [maéstro] & [máestro] \\
\hline & Rafael & [T̃afaél] & [rafáel] \\
\hline & creía & [kreía] & [kréia] \\
\hline & caído & [kaído] & [káydo] \\
\hline & trae & [tráe] & [traé] \\
\hline \multicolumn{4}{|l|}{ Vowel change } \\
\hline & río & [ñóo] & [ríúu \\
\hline & oscuro & [oskúro] & [eskúro] \\
\hline & peor & [peór] & [piór] \\
\hline & creer & [kreér] & [kre:r] \\
\hline & realmente & [F́éalménte] & [ríálménte] \\
\hline & ahogo & [aógo] & [ógo] \\
\hline & creemos & [kreémos] & [krémos] \\
\hline & reírse & [r̄eírse] & [rírse] \\
\hline
\end{tabular}




\begin{tabular}{|c|c|c|c|}
\hline \multicolumn{4}{|l|}{ Consonantal change } \\
\hline \multirow{7}{*}[\mathrm{d},\mathrm{l},\mathrm{r}]{} & ataúd & fataúd] & Jatát \\
\hline & darle & Idárle] & [ataui] \\
\hline & & & [dále] \\
\hline & almuerzo & [almwérso] & [armwérso] \\
\hline & admirada & [admirảda] & [almiráda] \\
\hline & admitimos & [admitímos] & [admitímos] \\
\hline & matarla & [matárla] & [matal:a] \\
\hline \multicolumn{4}{|l|}{ [nasals] } \\
\hline & ignoraba & [ignorába] & [in:orába] \\
\hline & magníficas & [magnífikas] & [man:ífikas] \\
\hline & himno & [ímno] & [ínno] \\
\hline \multicolumn{4}{|l|}{$[\mathrm{p}, \mathrm{b}, \mathrm{k}]$} \\
\hline & absolutamente & [absolútaménte] & [aksolútaménte] \\
\hline & abuela & [abwéla] & [agwéla] \\
\hline & cápsula & [kápsula] & [káwsula] \\
\hline & auxilio & [awksílyo] & [awsílyo] \\
\hline & huevos & [wébos] & [gwébos] \\
\hline & padre & [pádre] & [págre] \\
\hline & vómitos & [bómitos] & [gómitos] \\
\hline & aceptamos & [aseptámòs] & [asektámos] \\
\hline & pupitre & [pupitre] & [kupítre] \\
\hline & inyección & [inyeksyón] & [inyesyón] \\
\hline & perfectas & [perféktas] & [perfet:as] \\
\hline \multicolumn{4}{|l|}{$[\mathrm{f}, \mathrm{h}]$} \\
\hline & difunta & [difúnta] & [dihúnta] \\
\hline & jomalero & [hornaléro] & [fornaléro] \\
\hline & afuera & [afwéra] & [ahwéra] \\
\hline & Felipe & [felípe] & [helípe] \\
\hline & fogón & [fogón] & [hogón] \\
\hline & fue & [fwe] & [hwe] \\
\hline
\end{tabular}

\section{REFERENCES}

Anshen, F. (1969). Speech variation among Negroes in a small southern community. Doctoral dissertation, New York University.

Berk-Seligson, S. (1978). Phonological variation in a synchronic/diachronic sociolinguistic context: The case of Costa Rican Spanish. Doctoral dissertation, University of Arizona.

Berk-Seligson, S. \& Seligson, M. A. (1978). The phonological correlates of social stratification in Costa Rican Spanish. Lingua, 46, 1-28.

Bourhis, R. Y., \& Giles, H. (1976). The language of cooperation in Wales: A field study. Language Sciences, 42, 13-16.

Bourhis, R. Y., Giles, H. \& Lambert, W. E. (1975). Social consequences of accommodating one's style of speech: A cross-national investigation. In R. Cooper (Ed.), Language Attitudes II: International Journal of the Sociology of Language, 6, 55-71. 
Brown, B. L. (1969). The social psychology of variations in French Canadian speech styles. Doctoral dissertation, McGill University.

Carranza, M. A., \& Ryan, E. B. (1975). Evaluative reactions of bilingual Anglo and Mexican American spẹakers of English and Spanish. In R. Cooper (Ed.), Language Attitudes II: International Journal of the Sociology of Language, 6, 83-104.

Castillo, G. \& de Castillo, J. C. (1973). Personal communication, Agua Buena de Coto Brus, Costa Rica.

Cook-Gumperz, J. (1975). The child as practical reasoner. In M. Sanches \& B. G. Blount (Eds.), Sociocultural dimensions of language use. New York: Academic Press.

Cooper, R. L. (1975). Introduction. In R. L. Cooper (Ed.), Language Attitudes II: International Journal of the Sociology of Language, 6, 5-10.

Cooper, R. L., Fishman, J. A., Lown, L., Schaier, B. \& Seckbach, F., (1977). Language, technology and persuasion in the Middle East: Three experimental studies. In H. Giles (Ed.) Language, Ethnicity, and intergroup relations. London: Academic Press.

D'Anglejan, A, \& Tucker, G. R. (1973). Sociolinguistic correlates of speech style in Quebec. In R. W. Shuy \& R. W. Fasold (Eds)., Language attitudes: Current trends and prospects. Washington, D.C.: Georgetown University Press.

El-Dash, L, \& Tucker, G. R. (1975). Subjective reactions to various speech styles in Egypt. In R. L. Cooper (Ed.), Language Attitudes II: International Journal of the Sociology of Language, 6, 33-54.

Fasold, R. W. (1968). A sociolinguistic study of the pronunciation of three vowels in Detroit speech. Washington, D.C.: Center for Applied Linguistics. (Mimeo)

Flores, N. de la Z., \& Hopper, R. (1975). Mexican Americans' evaluations of spoken Spanish and English. Speech Monographs, 42, 91-98.

Gaertner, S., \& Bickman, L. (1971). Effects of race on the elicitation of helping behavior: The wrong number technique. Journal of Personality and Social Psychology, 20, 218-222.

Giles, H. (1970). Evaluative reactions to accents. Educational Review, 22, 211-227.

Giles, H. (1971). Ethnocentrism and the evaluation of accented speech. British Journal of Social and Clinical Psychology, 10, 197-198.

Giles, H. (1973). Accent mobility: A model and some data. Anthropological Linguistics, 15, $87-105$.

Giles, H., \& Bourhis, R. Y. (1975): Linguistic assimilation among West Indian immigrants in a British city. Language Sciences, 38, 9-12.

Giles, H., \& Bourhis, R. Y. (1976). Black speakers with white speech-A real problem? In G. Nickel (Ed.), Proceedings of the Fourth International Congress of Applied Linguistics. Stuttgart: . HochschulVerlag.

Gumperz, J. J., \& Herasimchuk, E. (1975). The conversational analysis of social meanings: A study of classroom interaction. In M. Sanches \& B. B. Blount (Eds.), Sociocultural dimensions of language use. New York: Academic Press.

Keenan, E. (1973). Conversational competence in children. Unpublished manuscript.

Keenan, E. (1974). Again and again: The pragmatics of imitation in child language. Unpublished manuscript.

Labov, W. (1964). Hypercorrection by the lower middle class as a factor in linguistic change. In W. Bright (Ed.), Proceedings of the UCLA Sociolinguistics Conference. Hawthorne, N.Y.: Mouton.

Labov, W. (1965). Stages in the acquisition of standard English. In R. Shuy (Ed.), Social dialects and language learning. Champaign, Illinois: National Council of Teachers of English. 
Labov, W. (1966). The social stratification of English in New York City. Washington, D.C.: Center for Applied Linguistics.

Labov, W. (1972). Sociolinguistic patterns. Philadelphia: University of Pennsylvania Press.

Lambert, W. E. (1967). A social psychology of bilingualism. Journal of Social Issues, 23, 91-109.

Lambert, W. E., Anisfeld, M., \& Yeni-Komshian, G. (1965). Evaluative reactions of Jewish and Arab adolescents to dialect and language variation. Journal of Personality and Social Psychology, 2, 84-90.

Lambert, W. E., Frankel, H., \& Tucker, G. R. (1966). Judging personality through speech: A French-Canadian example. Journal of Communications, 4, 305-321.

Lambert, W. E., Hodgson, R. C., Gardner, R. C., \& Fillenbaum, S. (1960). Evaluational reactions to spoken languages. Journal of Abnormal and Social Psychology, 60, 44-51.

Lee, R. R. (1971). Dialect perception: A critical review and re-evaluation. Quarterly Journal of Speech, 57, $410-417$.

Levine, L., \& Crockett, H. J., Jr. (1966). Speech variation in a Piedmont community: Postvocalic r. In S. Lieberson (Ed.), Exploration in Sociolinguistics (Sociological Inquiry, $36(2))$.

Markel, N. N., Eisler, R. M., \& Reese, H. W. (1967). Judging personality from dialect. Journal of Verbal Learning and Verbal Behavior, 6, 33-35.

Mejía Mejía, F. (1973). Personal communication.

Mitchell-Kernan, C., \& Kernan, K. (1975). Children's insults: America and Samoa. In M. Sanches \& B. B. Blount (Eds.), Sociocultural dimensions of language use. New York: Academic Press.

Osgood, C., Suci, G. J., \& Tannenbaum, P. H. (1957), The measurement of meaning. Urbana: University of Illinois Press.

Powesland, P., \& Giles, H. (1975). Persuasiveness and accent-message incompatibility. Human Relations, 28, 85-93.

Scotton, C. M. (1972). Choosing a lingua franca in an African capital. Edmonton: Linguistic Research.

Seligson, M. A. (1980). Peasants of Costa Rica and the development of agrarian capitalism. Madison: University of Wisconsin Press.

Seligson, M. A., \& Berk-Seligson, S. (1978). Language and political behavior: A methodology for utilizing the linguistic component of socioeconomic status. American Journal of Political Science, 22, 713-741.

Shuy, R. W. (1968). A study of social dialects in Detroit. Final Report, Project No. 6-1347. Washington, D.C.: U.S. Department of Health, Education, and Welfare, Office of Education; Bureau of Research.

Shuy, R. W., Wolfram, W. A., \& Riley, W. K. (1967). Linguistic correlates of social stratification in Detroit speech. Cooperative Research Project No. 6-1347. Washington, D.C.: Office of Education.

Trudgill, P. (1972). Sex, covert prestige and linguistic change in the urban British English of Norwich. Language in Society, 1, 179-195.

Trudgill, P. (1974). The social differentiation of English in Norwich. Cambridge, England: Cambridge University Press.

Tucker, G. R., \& Lambert, W. E. (1969). White and Negro listeners' reactions to various American-English dialects. Social Forces, 47, 463-468.

Tucker, G. R., \& Lambert, W. E. (1972). White and Negro listeners' reactions to various American-English dialects. In Joshua A. Fishman (Ed.), Advances in the sociology of language (Vol. 2). The Hague: Mouton. 
Williams, F., Hewett, N., Miller, L., Naremore, R., \& Whitehead, J. L. (1972). Explorations of the linguistic attitudes of teachers. Rowley, Massachussetts: Newbury House.

Wolck, W. (1973). Attitudes toward Spanish and Quechua in bilingual Peru. In R. Shuy \& R. Fasold (Eds), Language attitudes: Current trends and prospects. Washington, D. C.: Georgetown University Press.

Wolfram, W. A. (1969). A sociolinguistic description of Detroit Negro speech. Washington, D.C.: Center for Applied Linguistics.

Wolfram, W. A., \& Christian, D. (1976). Appalachian speech. Arlington, Virginia: Center for Applied Linguistics.

Wolfram, W. A., \& Fasold, R. (1974). The study of social dialect in American English. Englewood Cliffs, New Jersey: Prentice-Hall. 